\title{
Optimization of Virgin Coconut Oil (VCO) Production with Diffuser Type Aeration Method
}

\author{
Nyoman Sri Widari, Rahaju Saraswati, and Bambang Sutejo
}

\begin{abstract}
Virgin coconut oil (VCO) is pure coconut oil with low free fatty acid content and high lauric acid content. VCO has been produced in many home industries where the yield obtained is still very small. So, the researchers tried to find a more efficient production process so that they could obtain high process yields. Researchers made VCO using the aeration method with a diffuser type aerator. The experimental variables were air flow rate $(\mathrm{L} / \mathrm{min}): 0.6 ; 1.8 ; 4.0 ; 4,5$ and the duration of the aeration process (hours): $2 ; 3 ; 4 ; 5$, by using coconut milk from $1 \mathrm{~kg}$ of grated coconut in 1 liter of water, the maximum yield is $33.5 \%$ at an air flow rate of $4.0 \mathrm{~L} / \mathrm{min}$ with an aeration time of 4 hours. The quality of VCO obtained were: water content of $0.02 \%$; iodine number $5,54 \%$; peroxidation number $1.36 \mathrm{~g} .10 d / 100 \mathrm{~g} ; \mathbf{0 . 1 9 \%}$ free fatty acids; saturated fatty acid content of $93.71 \%$ and unsaturated fatty acid $6.24 \%$ and the color is very clear. The quality test results obtained are in accordance with the quality standards required by SNI 73812008.
\end{abstract}

Index Terms - Optimization, Production, VCO, Aeration, Diffuser.

\section{INTRODUCTION}

Coconut tree (Cocos nucifera L) is a plant that has a lot of benefits, starting from the roots, stems, leaves and fruit. Coconut fruit is an inseparable part of people's life, be it ripe and unripe. The ripe fruit pulp with 50\% water content is a source of nutrition which is full of coconut milk which tastes delicious and has a high oil content, so it is widely used as a food source. Coconut fruit which has a high oil content is a potential source of vegetable oil, even the oil yield can reach $30-40 \%$ [1].

Pure coconut oil or better known as Virgin Coconut Oil (VCO) is oil derived from coconut starch which is processed hygienically with very low heating even without heating and without chemical processes. VCO clear color, low water content and free fatty acids with high lauric acid content. VCO also contains high anti-oxidants so that it can maintain immunity. If there are contaminants, it will reduce the quality of VCO. With the high content of medium and short chain unsaturated fats, it does not cause disease because it is easily absorbed by the body and quickly processed into energy. With the chemical structure of saturated fatty acids that do not have double bonds, muri coconut oil or VCO is relatively more special than other cooking oils.

There are several ways to extract the oil from the pulp, by chemically and physically. Chemical process can use nonpolar solvents (solvent extraction), by means of fermentation or by using enzymatics. While physical processing can be done by heating (rendering), by means of aeration, stirring and usually using fresh coconut which is made of coconut milk with a moisture content of about $50 \%$ and pressing method, which is the method used when the raw material is copra or coconut. dry. Oil processing with this pressing method obtains crude oil with low quality, dark color and smells strong and rancid so it is necessary to carry out further processing with the help of chemicals in order to obtain standard quality oil. Commonly produced coconut oil products are ordinary coconut oil (OCO) and virgin coconut oil, better known as VCO, which have a price three times higher.

Extraction of coconut oil by fermentation of Saccharomyces cereviceae [2] is concluded that with a fermentation time of 18 hours and a starter amount of $5 \%$ by weight of coconut cream, an optimum yield of $60.36 \%$ was obtained, while [3] carried out the extraction process by fermentation of Saccharomyces cereviceae. the highest was $23 \%$ with a protein content of $0.05 \%$; fat $96.45 \%$; free fatty acids $0.29 \%$ and cholesterol $0.008 \%$. Making Vigin Coconut Oil (VCO) enzymatically using crude papain, the highest yield was obtained, namely the treatment of $0.06 \%$ crude papain and an incubation temperature of $40 \mathrm{C}$ which produced $49.07 \%$ yield with the following specifications: lathering rate of $258.57 \mathrm{mg} \mathrm{KOH} \mathrm{/} \mathrm{g;} \mathrm{free} \mathrm{fatty} \mathrm{acids} 0.38 \%$; peroxide rate $0.701 \%$; red color 0.3 ; yellow 0.2 , white 0.2 . With the conclusion that the quality of VCO has met SNI standards [4]. The study, which was carried out with the salting method using $\mathrm{CaCl} 2$ salt, obtained the highest yield of $26.9 \%$, namely the time or duration of salting 36 hours with a salt weight of 3 grams and the level of lauric acid contained in VCO was $51.1 \%$ [6]. Changes in yield and quality of VCO at various rotation speeds and length of centrifugation time obtained the highest yield of $26.99 \%$ at a rotation speed of $10,000 \mathrm{rpm}$ with a centrifugation duration of 20 minutes [5]. Meanwhile, making VCO with the aeration method using a variable operating time, hole size and the number of spargers used, it can be concluded that the longer the aeration process takes, the more VCO is obtained, but there is a limit where the additional time actually reduces the VCO gain. With the addition of 2 sparger, it turns out to reduce the VCO recovery and the smaller the VCO sparger hole size, the more is obtained [7].

Based on the research that has been done, it turns out that there are not many researches on VCO making using the aeration method so that research with the aeration method is
Submitted on May 18, 2021.

Published on June 30, 2021.

Nyoman Sri Widari, WR Supratman University, Indonesia.

(e-mail: nyomansri.widari@gmail.com)
Rahaju Saraswati, WR Supratman University, Indonesia. (e-mail: rahayu saraswati12@yahoo.co.id) Bambang Sutejo, WR Supratman University, Indonesia. (e-mail: bamsitats@gmail.com). 
still feasible to continue. In this study, it is planned to use a diffuser type aerator that can transfer compressed air that is injected into coconut milk. The purpose of this research is to obtain optimal VCO with quality that meets the SNI 7381: 2008 standard using the aeration method. The research was conducted by combining the air flow rate used for the aeration process with the length of the process. The benefit of research is to be able to provide information to the public one way of making VCO that is applicable, cheap and easy with very simple technology but can produce quality VCO that meets the SNI.7381: 2008 standard.

The aeration process is the occurrence of entering air into a liquid which will be processed by blending, namely the air is allowed to blend or dissolve in the liquid. To obtain VCO with the aeration method, it is done by flowing air into the coconut milk so that more and more air bubbles are trapped in the coconut milk, as a result the air is more and more diffused or dissolved in the liquid. The aeration method emphasizes the transfer of air into coconut milk so that it can break down the oil that is held in the coconut milk and then isolate it so that the oil will be easier to separate. There are several types of aeration processes that are widely applied, including gravity aerators, spray aerators, diffuser aerators and mechanical aerators. The diffuser type aerator can transfer compressed air which is injected into coconut milk. Air injection takes place in the trough via a porous diffuser [8]. The air that comes out of the diffuser is usually in the form of fine bubbles which can cause increased turbulence in coconut milk. The principle of separating oil by the aeration method is the effect of foam and air bubbles trapped in the coconut milk during aeration and it is this air bubble that causes the oil to be isolated from the coconut milk, giving rise to a layer of oil in the coconut milk. Coconut milk is a white liquid obtained from the pressing or squeezing process of fresh coconut flesh which is carried out with or without water so that coconut milk is a form of oil-in-water emulsion [9].

VCO oil has a very clear color almost like mineral water, has a distinctive aroma because it still contains natural phytonutrients from coconut, with a lauric acid content of more than $50 \%$ and caprylic acid above $7 \%$ and contains vitamin $\mathrm{E}$ (tocophenol) higher than RBD coconut oil almost 30 times. VCO has properties that are stable, not easily damaged to heat, resistant to light and air, resistant to degradation, at temperatures below $25^{\circ} \mathrm{C}$ in the form of solid / frozen white, while above $25{ }^{\circ} \mathrm{C}$ in the form of liquid and clear [10]. Because it is processed from the breakdown of coconut milk emulsion without heating or without the addition of chemicals so that the oil is said to be virgin, VCO is a vegetable oil composed of several fatty acids that are bound as triglycerides (triglyceride fatty acids). The benefits of VCO are as anti-bacterial, as anti-viral, maintain healthy skin and hair, as a moisturizer, reduce health risks (heart, liver, diabetes, cancer, etc.), increase immunity, both for pregnant and lactating women, and many more. other [11].

\section{RESEARCH METHOD}

\section{A. Experimental Design}

This type of research is an experiment conducted in a laboratory using a bulk reactor on a laboratory scale. This study used a Completely Randomized Design (CRD). The independent variables in this study were air flow rate: 0.6 ; $1.8 ; 4.0 ; 4.5(\mathrm{~L} / \mathrm{min})$ and the duration of the aeration process: $2 ; 3 ; 4 ; 5$ (hours) where each run is analyzed twice. The dependent variable is the amount of oil obtained and the control variable is the ratio of water and weight of grated coconut meat $(1 \mathrm{lt}: 1 \mathrm{~kg})$, the position of the diffuser in the middle, the process is run at room temperature, with an air pump pressure of $>0.010 \mathrm{Mpa}$.

\section{B. Materials and Tools}

The materials used in the study were old and fresh coconut, clean water, and several chemicals as reagents, while the equipment used was grated coconut, coconut milk filter, separating funnel, beaker glass, erlenmeyer, measuring glass, a set of diffusers, a thermometer, analytical balance, filter paper.

\section{Reactor Set Up}

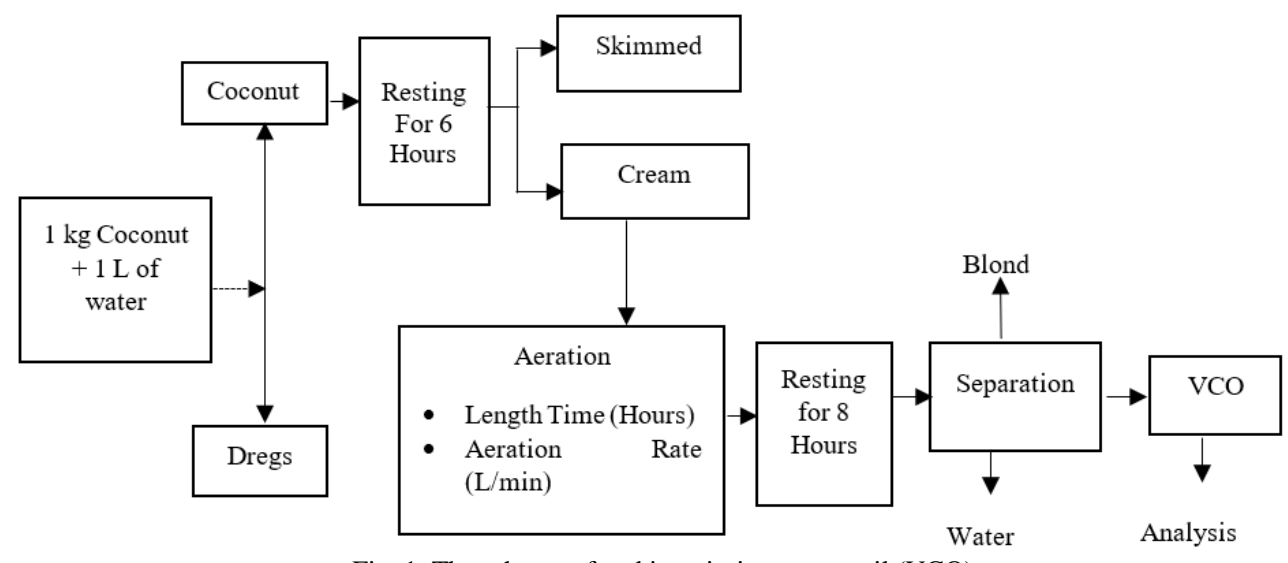

Fig. 1. The scheme of making virgin coconut oil (VCO).

\section{Research Method}

\section{Making of coconut milk}

The coconuts used are old and fresh coconuts which are marked with a brown color on the shell and when shaken the water inside will sound loud. The shredded coconut is extracted with water at a ratio of 1 liter of water to $1 \mathrm{~kg}$ of grated coconut. Furthermore, stirred and squeezed then filtered until get a thick coconut milk. The coconut milk is then deposited in a transparent container for 2 hours to form 
coconut cream and skimmed coconut milk. Coconut cream is on the top layer which contains a lot of oil and skimmed coconut milk is on the bottom layer because it contains a lot of water.

\section{Making of $\mathrm{VCO}$}

The coconut cream obtained is put into a transparent container equipped with an aeration diffuser system at the base and the center position. The aeration process was carried out with aeration rates $(0.6 ; 1.8 ; 4.0$ and $4.5 \mathrm{~L} / \mathrm{min})$ and the length of the aeration process (2, 3, 4, and 5 hours). Then the cream that has undergone an aeration process according to the predetermined variables is left to rest for 8 hours until three clear layers are formed where the bottom layer is water, the middle layer is Blondo, and the top layer is oil (VCO). VCO which is at the top is taken slowly using a pipette, then filtered using filter paper so that no protein-containing blondo is included so the results are really clear [12].

\section{Analysis}

The VCO obtained is then analyzed including yield [9], and quality analysis based on the requirements of SNI 7381: 2008 [13]. The VCO yield is calculated based on the VCO weight obtained compared to the weight of grated coconut meat used X 100\%. Meanwhile, for quality analysis using GCMS (Gas Chromatography Mass Spectrofotometry). Organoleptic testing was carried out by means of a hedonic test for smell, taste, and color on a scale: like (1), like (2), normal (3), and dislike (4).

\section{RESULT AND DISCUSSION}

Oil yield was calculated to determine the amount of VCO produced from the extraction of shredded coconut meat using the diffusion aeration method. The yield is calculated based on the percentage of the amount of VCO obtained per unit weight of grated coconut meat used. The VCO yield obtained from the aeration process ranged from $13.5 \%-33.5 \%$ and the overall average yield was $24.6 \%$.

From Fig. 2 it can be seen that the effect of the length of the aeration process is very significant on the VCO yield obtained, the longer the aeration process the more VCO is obtained but to a certain extent the VCO produced is constant. This is because the VCO content in the coconut cream has been extracted maximally, although the added processing time will not increase the amount of VCO obtained. Likewise, the effect of the air volume rate (aeration rate) on the \% yield obtained in the coconut cream extraction process, the greater the aeration rate the greater the yield $\%$ obtained but to a certain extent. The highest yield was $33.5 \%$, which was obtained in a 4-hour process with an aeration rate of 4.0 $\mathrm{L} / \mathrm{min}$. The yield obtained as much as $33.5 \%$ was included in the yield range presented in [1], namely the yield of oil obtained was around $30 \%$ to $40 \%$.

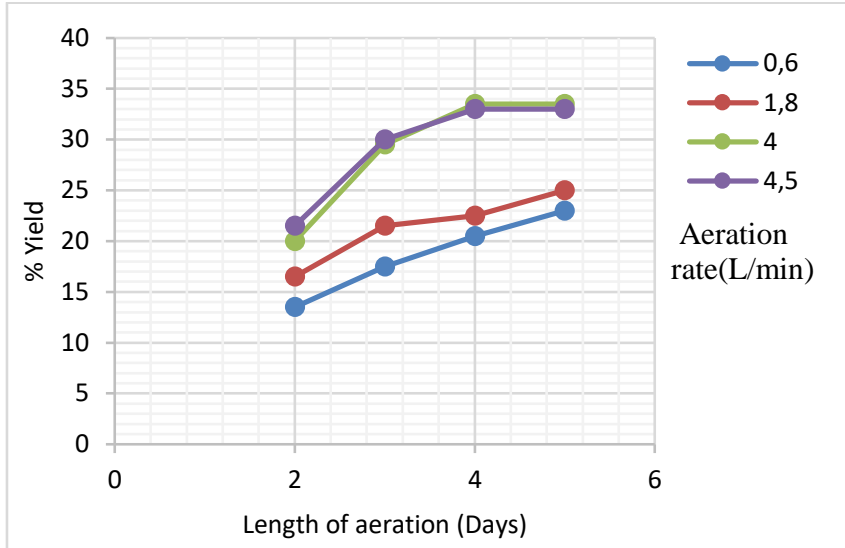

Fig. 2. Graph the length of the aeration process with the rate of air volume in VCO extraction against the yield\% produced.

The yield obtained is still not optimal, which is still below $40 \%$, this is probably due to several factors: first the coconut squeezing process is not optimal because in the coconut dregs there is still a high enough retained oil, so that the process of impregnation is more effective to use a crusher so that the oil content in the dregs can be extracted all. The second possibility is that the aeration process with the diffusion method is less effective where the diffuser is only placed in the middle, to be more effective the diffuser needs to be evenly placed on the bottom of the container. The three-oil content in coconuts is strongly influenced by the quality of the coconut fruit, which is determined by the coconut plant variety, plant age, fruit health, soil conditions and climate.

The hedonic test results on the smell of VCO with a scale of like (1), rather like (2), normal (3) and dislike (4) with an overall average value of 2.4 (rather like) means that the VCO obtained from this study smells. The respondents liked it somewhat, namely it had a distinctive smell of fresh coconut and was not rancid. So, the results of the hedonic test for odors are in accordance with the requirements of SNI 7381: 2008. The smell of commercial coconut oil does not have a distinctive taste like VCO because it has undergone a heating and refining process.

The results of the hedonic test on the taste of VCO with the same scale as the hedonic test for odors, obtained results with an overall average value of 2.2 (rather like) which means that the respondent likes the taste of the VCO produced. According to the SNI requirements, VCO must taste normal especially coconut oil.

The hedonic test results on the color of the VCO produced on a scale of very clear (1), clear (2), somewhat clear (3) and not clear (4), obtained an average value of 1.45 (very clear) which means that the color of the VCO is produced has met the standards required by SNI, namely clear, colorless to pale yellow.

These physical properties indicate that the process of breaking the coconut emulsion without a sweetening process or without the addition of chemicals so that the oil structure is not damaged and is still virgin so that VCO is widely used for healing various diseases and other healthy life. VCO is also recommended to be routinely consumed as a health supplement [11]. Quality coconut oil is clear yellow to colorless with normal taste and distinctive odor of coconut oil, while poor quality oil smells rancid, has an abnormal brown color and odor [12]. 
TABLE I: COMPARISON OF THE VCO COMPOSITION OF RESEARCH RESULTS WITH VCO ACCORDING TO SNI 7381: 2008

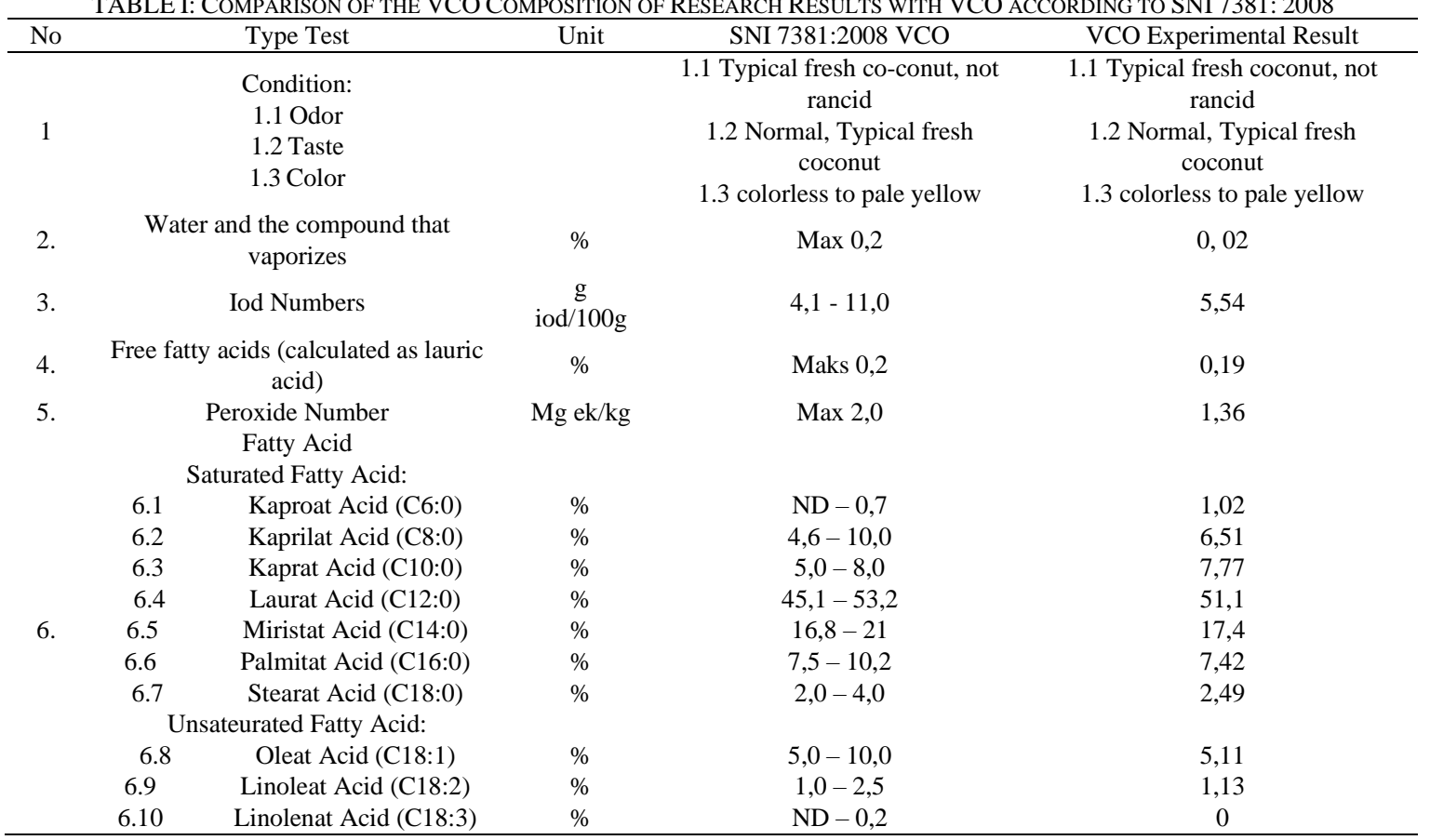

The water content in the oil is one of the parameters that greatly influences the storage capacity, the higher the water content in the oil will accelerate the oxidation process, giving rise to a rancid smell in the oil [18]. To maintain the quality of the oil, the water content in the oil must be kept as low as possible. The presence of water in oil or fat can cause a hydrolysis reaction that can change the oil or fat into free fatty acids and glycerol, this reaction causes the oil to smell rancid [21], [19], [9]. High water content can also lead to bacterial contamination which can hydrolyze fat molecules [14]. The water content obtained from the research results was $0.02 \%$, where this level met the quality requirements of SNI 73812008 coconut oil with a maximum water content of $0.2 \%$ and also met the Codex standard, namely 0.1-0.5\%. [15].

Levels of free fatty acids (Free Faty Acid / FFA) are naturally found in coconut oil and are also closely related to the presence of water in the oil. Free fatty acids are formed due to the hydrolysis reaction by a number of water in the oil, enzymes and the activity of microorganisms The presence of free fatty acids (FFA) in oil is one of the parameters for oil damage caused by the hydrolysis reaction between water and fat which can produce glycerol and fatty acids [16], [17]. The higher the water content in the oil, the higher the free fatty acid content [6]. So, to suppress free fatty acid levels, the water content must be as low as possible. The lower the free fatty acid content in the oil the better the quality of the oil. The results showed that the free fatty acid (FFA) content was $0.19 \%$, while the required quality standard according to SNI 7381-2008 was $0.2 \%$ maximum and according to Codex standards was $1.3 \%$.

The VCO obtained has distinctive physical properties compared to other oils because it is clear in color with a different aroma when compared to oils from copra or olive oil. The aroma of VCO is widely liked so that it can be consumed directly to get its health benefits. From the analysis of the main component of VCO in the form of medium chain saturated fatty acids (MCSFA), namely from caprylic acid (C8), karpic acid (C10) and lauric acid (C12). Lauric acid is present in breast milk (ASI) and is a source of important nutrients in the formation of antibodies in the human body. Lauric acid is also widely used by many industries, especially the main fatty acid contained in VCO is lauric acid (C12) which is equivalent to the baby food industry and the pharmaceutical industry. In the pharmaceutical industry, lauric acid and VCO are widely used as anti-viral and bacterial drugs. In the soap, detergent and perfume industry, lauric acid is widely used as a surfactant or binder. The higher the lauric acid content of the VCO, the higher the quality of the VCO and the higher the benefits for health. The research data showed that the VCO obtained consisted of $93.71 \%$ saturated fatty acids and $6.24 \%$ in the form of unsaturated fatty acids. Of the $93.71 \%$ saturated fatty acids contained in VCO $65.38 \%$ were medium chain saturated fatty acids, namely caprylic acid (C8), capric acid (C10) and lauric acid (C12). The main parameter of saturated fatty acid is lauric acid (C12), the higher the level of lauric acid in the oil, the higher the quality of the oil. The VCO results showed that the level of lauric acid (C12) was $51.1 \%$, while the quality standards required according to SNI 7381-2008 were 45.1$53.2 \%$. While the results of research conducted [18] the lauric acid content of copra oil was $36.2 \%$, the lauric acid content of olive oil was $1.34 \%$ and the lauric acid content of VCO with the fermentation process was $46.7 \%$. In addition to containing medium chain saturated fatty acids, the VCO also contains long chain saturated fatty acids in the form of palminic acid (C16) and stearic acid (C18-0) as much as $9.91 \%$, and long chain unsaturated fatty acids as much as $6.24 \%$ in the form of oleic acid (C18-1), linoleic acid (C182). Long-chain unsaturated fatty acids have large molecular sizes which are dangerous to health because if they are used for frying or under heating, they polymerize to form trans fatty acids and free radicals which are toxic.

\section{CONCLUSIONS}

From the optimization research of making virgin coconut oil (VCO) by aeration method with experimental design using 
randomized block design involving two factorials, namely the air flow rate in the aeration process $(0.6 ; 1.8 ; 4.0 ; 4.5) \mathrm{L} / \mathrm{min}$ and the duration of the aeration process $(2 ; 3 ; 4 ; 5)$ hours using coconut milk from $1 \mathrm{~kg}$ of grated coconut in 1 liter of water. The maximum yield of $33.5 \%$ is at an air flow rate of $4.0 \mathrm{~L} / \mathrm{min}$ with an aeration process of 4 hours. The result of the organoleptic test of the resulting VCO showed that the odor parameter obtained an average value of 2.4 which means a little like, the taste parameter with a value of 2.2 which means also a little like and the color parameter with a value of 1.45 which means very clear. While the water content in the VCO results of the study was $0.02 \%$, the iodine number was $5.54 \%$, the peroxid number was $1.36 \mathrm{~g} .10 d / 100 \mathrm{~g}$, free fatty acids (FFA) $0.19 \%$, saturated fatty acid content was $93.71 \%$ and $6.24 \%$ unsaturated fatty acids. All of the quality test results obtained are in accordance with the required quality standards according to SNI 7381-2008.

\section{REFERENCES}

[1] Soedijanto Sianipar, RRM. 1984. Kelapa. CV. Yasaguna, Yogyakarta.

[2] Purwana Canra, K. 2006. Aplikasi Fermentasi Menggunakan Saccharomyces Cereviciae Pada Krim Kelapa Untuk Ekstraksi Minyak. Jurnal Teknologi Pertanian . Maret 2006: 68-73.

[3] Sudaryati Soeka,Y., Sulistyo,J., Naiola,E. 2008. Analisis Biokimia Minyak Kelapa Hasil Ekstraksi Secara Sermentasi. Biodiversitas, vol 9. No 2. April 2008. 91-95.

[4] Winarti,S., Jariyah., Purnomo,Y. 2007. Proses Pembuatan Virgin Coconut Oil Secara Enzimatis Menggunakan Papain Kasar. Jurnal Teknologi Pertanian. Vol. 8. No.2. Agustus 2007: 136-141.

[5] Anwar,C., Reza S. (2016). Perubahan Rendemen dan Mutu Virgin Coconut Oil pada Berbagai Kecepatan Putar dan Lama Waktu Sentrigugasi. Jurnal Teknotan Vol. 10 No.2, November 2016.51-60.

[6] Aziz,T., Yohana,O., Ade Puspita,S. 2017. Perbuatan Virgin Coconut Oil (VCO) dengan Metode Penggara, man. Jurnal Teknik Kimia no.2, Vol. 23, April 2019: 127-137.

[7] Purwanto, D. 2006. Proseding Seminar Teknik Kimia Universitas Riau.

[8] Batara,K.,Badrus,Z.,Wiharyanto,O. 2017. Pengaruh Debit Udara dan Waktu AerasiTerhadap Efisiensi Penurunan Besi dan Mangan Menggunakan Diffuser Aerator Pada Air Tanah. Jurnal Teknik Lingkungan Universitas Diponogoro. Vol. 6. No. 1.

[9] Ketaren,S. 1986. Pengantar Teknologi Minyak dan Lemak Pangan. 3036. Universitas Indonesia Press, Jakarta.

[10] Norulaini, N. 2009. Effects of Supercritical Carbon Dioxide Extraction Parameters on Virgin Coconut Oil Yield and Medium- Chain Triglyceride Content. Journal of Food Chemistry. Volum 116, Issue 1, September 2009. Page 193-197.

[11] Setyopratiwi, A. 2005. Menguak Fenomena Virgin Coconut Oil Dari Kaca Mata Chemist. FMIPA, UGM

[12] Hapsari, N., Welasih, T. 2010. Pembuatan Virgin Coconut Oil (VCO) Dengan Metode Sentryfugasi. REKAPANGAN. J. Teknologi Pangan 4: 341-349.

[13] Standarisasi Nasional Badan. 2008. SNI 7381-2008: Syarat Mutu Minyak Kelapa Virgin (VCO). Jakarta (ID). Badan Standarisasi Nasional.

[14] Raharja,S., Dwiyuni,M. 2008. Kajian Sifat Siko Kimia Ekstraksi VCO Dengan Metode Pembekuan Krim Santan. Jurnal Teknologi Industri Pertanian 18: 71-78.

[15] Codex Alemanterius. 1999. Codex Standart for Edible Fats and Oil not Covered by Individual Standarts. CODEX STAN 19-1981, Rev. 21999.

[16] Meilina, H., Asmawa., Moulana, R. 2010. Kajian Penambahan Ragi Roti dan Perbandingan Volume Starter Dengan Substrat Terhadap Rendemen dan Mutu Vigin Coconut Oil (VCO). Jurnal Reaksi (Journal of Science and Technology) 8: 25-33.

[17] Winoto,Y., Aulanni', Subagio,A., Widjanarko,SB. 2007. Ekstraksi virgin coconut oil secara enzimatis menggunakan protease dari tanaman biduri (Calotropis gigantea). Jurnal Agritech 27: 100-106.

[18] Wong, Y.C and Harna, H. 2014. Virgincoconut oil produc on by centriguga on method orient, J. Chem. 30: 237-245.

[19] Budiman, F., Ambari, O., Surest, A.H. 2015. Pengaruh waktu fermentasi dan perbandingan volume santan dan sari nanas pada pembuatan virgin coconut oil (VCO). Jurnal Teknik Kimia 18: 37-42.
[20] Erika, C., Yunita, D., Arpi, N.A. 2014. Pemanfaatan ragi tapai dan getah buah nanas pada ekstreaksi minyak kelapa secara fermentasi. Jurnal Teknologi Pertanian Indonesia 6: 1-6.

[21] Nodjeng, M.F., Rorong, A. 2013. Kualitas virgin cocnut oil yang dibuat pada metode pemanasan bertahap sebagai minyak goreng dengan penambahan wortel (Daucus corrots I). Jurnal Ilmiah Sain 13: 102-109. 